\title{
Preliminary Investigation On the Effect of Crumb Rubber (From Waste Tyre) On Nigerian Tar Sand Bitumen and Conventional 60/70
}

\author{
Olutaiwo Adewale O., Adewole Oluwatobi S.
}

\begin{abstract}
In this study, standard laboratory tests such as: Penetration, Viscosity, Softening Point, Specific gravity and Flash/Fire Point tests, were conducted on samples of crumb rubber-modified Tar sand bitumen and crumb rubber-modified conventional 60/70 bitumen, using crumb rubber replacement percentages of $0 \%, 2.5 \%, 5 \%, 10 \%, 12.5 \%$ and $15 \%$.
\end{abstract}

Index Terms - Bitumen, Crumb rubber (CR), Marshall Stability \& Flow, Tar Sand

\section{INTRODUCTION}

Nigeria's road network of about $200,000 \mathrm{~km}$ is largely in a bad state despite the fact that Nigeria is reputed for having the second largest deposit of bitumen in the world, spanning approximately 120 kilometers across Ogun, Ondo, Lagos and Edo State [1]. The estimated probable reserve of bitumen in Ondo state alone is 16 billion barrels, while that of Tar Sands and Heavy Oils is estimated at 42 billion barrels. Its primary use $(70 \%)$ is in road construction as a binder mixed with aggregate particles to form Asphalt Concrete [2]. About 80\% of Asphaltic materials used for road construction in the country is still being imported despite our vast bitumen deposit. The high cost of pavement construction makes it imperative to seek for alternatives to conventional bitumen. A rheological weakness of conventional bitumen has generated an increasing interest in the use of polymer-modified binders to enhance conventional bitumen properties [3]. To modify the natural bitumen obtained from tar sand, it is important to employ readily available and abundant waste material such as scrap tyre rubber.

Crumbed rubber tyre, $\mathrm{CR}$, is usually defined as rubber having a particle size of $9.5 \mathrm{~mm}$ (3/8 inch) or less [4].

Tar sand, also known as Bituminous Sand or Oil Sands are naturally occurring deposits containing loose sands or particularly consolidated sandstones that are saturated with highly viscous bitumen [5].

\section{MATERIALS AND METHODOLOGY}

The materials used in this research work include: Tar sand, Crumb rubber, and Conventional 60/70 Bitumen.

\subsection{Tar Sand}

Tar sand used for the purpose of this research was collected at Imeri village, Ijebu Mushin, Ijebu East Local Government area of Ogun state which lies between latitude $06^{\circ} 46^{\prime} \mathrm{N}$ and

Olutaiwo Adewale O., Department of Civil and Environmental Engineering, University of Lagos, Nigeria

Adewole Oluwatobi S., Post-graduate Student, Department of Civil and Environmental Engineering, University of Lagos, Nigeria
$06^{0} 47^{\prime} \mathrm{N}$ and longitudes $003^{0} 59^{\prime} \mathrm{E}$ and $003^{0} 59^{\prime} \mathrm{E}$ [8]. Its properties are highlighted in TABLES 1 and 2 below.

Table 1: Properties of Tar Sand Sample

Bitumen Saturation

\begin{tabular}{|l|l|l|}
\hline Samples & A & B \\
\hline Weight of Tar Sand $(\mathrm{g})$ & 2474.7 & 2468.2 \\
\hline Weight of Sand $(\mathrm{g})$ & 2008.5 & 2002.0 \\
\hline Weight of fillers $(\mathrm{g})$ & 283.4 & 278.2 \\
\hline Weight of bitumen $(\mathrm{g})$ & 182.8 & 177.6 \\
\hline \% of weight of Bitumen & 7.4 & 7.2 \\
\hline Average \% weight of bitumen & & 7.3 \\
\hline
\end{tabular}

Table 2: Gradation Analysis of Tar Sand

\begin{tabular}{|l|l|l|l|}
\hline Sieve sizes & $\begin{array}{l}\text { Cumulative } \\
\text { weight }\end{array}$ & $\begin{array}{l}\text { \% } \\
\text { Cumulative } \\
\text { retained }\end{array}$ & $\begin{array}{l}\text { \% } \\
\text { Cumulative } \\
\text { passing }\end{array}$ \\
\hline $\mathbf{2 5 m m}$ & - & - & - \\
\hline $\mathbf{1 9 . 5 m m}$ & - & - & - \\
\hline $\mathbf{1 2 . 5 m m}$ & - & - & - \\
\hline $\mathbf{9 . 5 m m}$ & 9.00 & 0.44 & 99.56 \\
\hline $\mathbf{4 . 7 5 m m}$ & 58.90 & 2.94 & 97.06 \\
\hline $\mathbf{2 . 3 6 m m}$ & 115.70 & 5.76 & 94.24 \\
\hline $\mathbf{1 . 1 8 m m}$ & 184.50 & 9.18 & 90.82 \\
\hline $\mathbf{6 0 0 m m}$ & 292.30 & 14.55 & 85.45 \\
\hline $\mathbf{3 0 0 m m}$ & 657.60 & 32.74 & 67.26 \\
\hline $\mathbf{1 5 0 m m}$ & 1684.50 & 83.86 & 16.14 \\
\hline $\mathbf{7 5 m m}$ & 2002.10 & 99.68 & 0.32 \\
\hline Pan & 2005.00 & & \\
\hline
\end{tabular}

\subsection{Crumb Rubber (CR)}

Crumb rubber (from Scrap tyres) used for this research was obtained from Tensquare Engineering Services Ltd, Lagos. Its properties are shown in TABLE 3.

Table 3: Properties of Crumb Rubber sample

\begin{tabular}{|l|l|l|}
\hline S/N & Properties & Test Result \\
\hline 1 & Size & Passing 600-micron sieve \\
\hline 2 & Specific gravity & 1.104 \\
\hline 3 & Moisture content & $0.84 \%$ \\
\hline
\end{tabular}

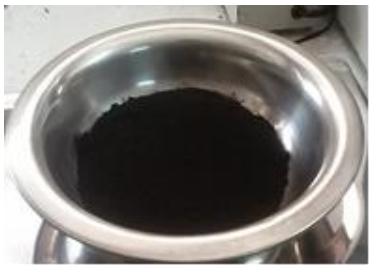

Figure 1: Crumb rubber sample 


\subsection{Conventional 60/70 Bitumen Sampling}

The 60/70 conventional bitumen used was collected from JB Euro65 lab supplied by ASCA Bitumen Ltd, Sapele, Nigeria. 2.4 Methodology

The series of laboratory tests conducted are listed in TABLE 4.

Table 4: List of Laboratory Tests Conducted

\begin{tabular}{|l|l|}
\hline Mixture & Test Conducted \\
\hline First Set of Tests (Preliminary Tests) \\
\hline \multirow{4}{*}{$\begin{array}{l}\text { Bitumen sample only } \\
\text { (60/70 ASCA, Tarsand } \\
\text { Bitumen) }\end{array}$} & Penetration \\
\cline { 2 - 2 } & Viscosity \\
\cline { 2 - 2 } & Specific Gravity \\
\cline { 2 - 2 } Second Set of Tests & Flash and Fire Point \\
\cline { 2 - 2 } $\begin{array}{l}\text { Bitumen Samples (60/70 } \\
\text { ASCA) } \\
+\end{array}$ & Softening Point \\
\cline { 2 - 2 } $\begin{array}{l}\text { Crumb Rubber }(2.5 \%-15 \%) \\
\text { Bitumen Samples (Tar Sand } \\
\text { Bitumen) } \\
+\end{array}$ & Penetration \\
\cline { 2 - 2 } \begin{tabular}{l} 
Crumb Rubber (2.5\% -15\%) \\
\cline { 2 - 2 }
\end{tabular} & Viscosity \\
\cline { 2 - 2 } & Specific Gravity \\
\cline { 2 - 2 } & Softening Point \\
\cline { 2 - 2 } & Penetration \\
\cline { 2 - 2 } & Siscosity \\
\cline { 2 - 2 } & Specific Gravity \\
\hline
\end{tabular}

The laboratory tests were conducted according to ASTM D2172- Standard Test Method for bitumen extraction, ASTM D5/D5M - Standard Test Method for Penetration, ASTM D36 / D36M - Standard Test for Softening Point, , ASTM C136/ IS: 1206-1978-Standard Test for Viscosity by Tar Viscometer and ASTM C136- Sieve Analysis of aggregates.

\section{RESUlTS, ANALYSES AND DISCUSSIONS}

3.1 Effect of Crumb Rubber (CR) on Penetration value, Softening Point, Viscosity, Flash and Fire Point Values of Tar Sand Bitumen and 60/70 Conventional Bitumen

From the results obtained and listed in TABLES 5 and 6 , it was observed that penetration values decreased linearly for both tar sand bitumen and conventional 60/70 bitumen as crumb rubber content was varied. However, the values of softening point, viscosity, flash and fire point increased linearly. The results are shown diagrammatically in Fig 5, 6, 7,8 and 9.

Table 5: Effect of Crumb Rubber on Properties of Conventional 60/70 ASCA Bitumen

\begin{tabular}{|c|c|c|c|c|c|c|c|c|}
\hline \multirow{2}{*}{$\begin{array}{c}\text { LABORATORY } \\
\text { TESTS }\end{array}$} & \multirow{2}{*}{$\begin{array}{c}\text { BASE BITUMEN } \\
\text { PROPERTIES } \\
\text { (Unmodified) }\end{array}$} & \multicolumn{5}{|c|}{ CRUMB RUBBER REPLACEMENT (\%) } \\
\cline { 3 - 9 } & 2.5 & 5.0 & 7.5 & 10.0 & 12.5 & 15 & 20 \\
\hline Penetration & 62.6 & 43.9 & 41.2 & 40.5 & 37.5 & 31.2 & 25.4 & - \\
\hline Softening Point & 50.6 & 53.2 & 57.6 & 59.6 & 65.8 & 66.6 & 71.2 & - \\
\hline Viscosity & 22.5 & - & 23.5 & - & 25.5 & - & 27 & 28 \\
\hline Flash point & 150 & 185 & 210 & 210 & 220 & 221 & 225 & - \\
\hline Fire point & 235 & 240 & 243 & 250 & 255 & 260 & 265 & - \\
\hline
\end{tabular}

Table 6: Effect of Crumb Rubber on Properties of Tar Sand Bitumen

\begin{tabular}{|c|c|c|c|c|c|c|c|c|}
\hline & \multirow{7}{*}{ TEST } & $\begin{array}{c}\text { BASE BITUMEN } \\
\text { PROPERTIES } \\
\text { (Unmodified) }\end{array}$ & \multicolumn{7}{|c|}{ CRUMB RUBBER REPLACEMENT } \\
\cline { 3 - 9 } & $2.5 \%$ & $5.0 \%$ & $7.5 \%$ & $10.0 \%$ & $12.5 \%$ & $15 \%$ & $20 \%$ \\
\hline Penetration & 82 & 77.3 & 70.3 & 65.1 & 59.3 & 48.1 & 45.0 & - \\
\hline $\begin{array}{c}\text { Softening } \\
\text { Point }\end{array}$ & 50 & 60.2 & 62.5 & 67.4 & 69.8 & 73.0 & 75.8 & - \\
\hline Viscosity & 16 & - & 16.7 & - & 17.5 & - & 18 & 21 \\
\hline Flash point & 165 & 165 & 190 & 220 & 230 & 235 & 250 & - \\
\hline Fire point & 245 & 260 & 265 & 265 & 265 & 270 & 280 & - \\
\hline
\end{tabular}


International Journal of Engineering and Technical Research (IJETR)

ISSN: 2321-0869 (O) 2454-4698 (P) Volume-9, Issue-11, November 2019

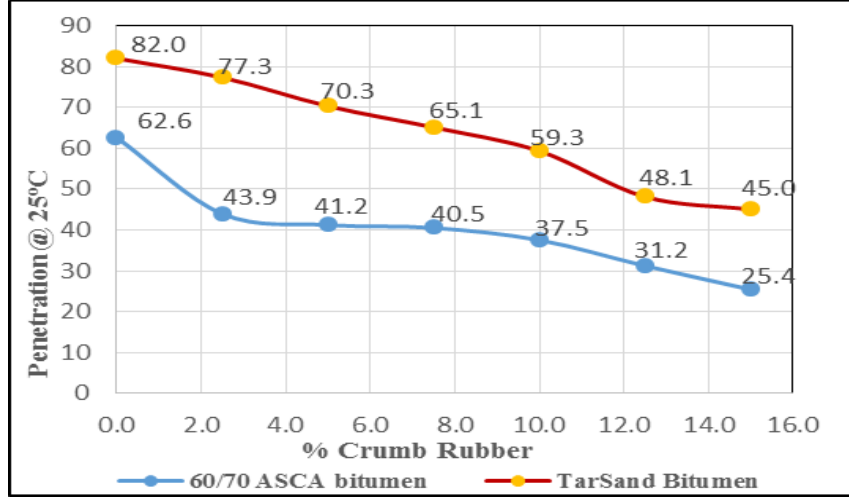

Figure 5: Variation of Penetration with Crumb rubber (CR) content

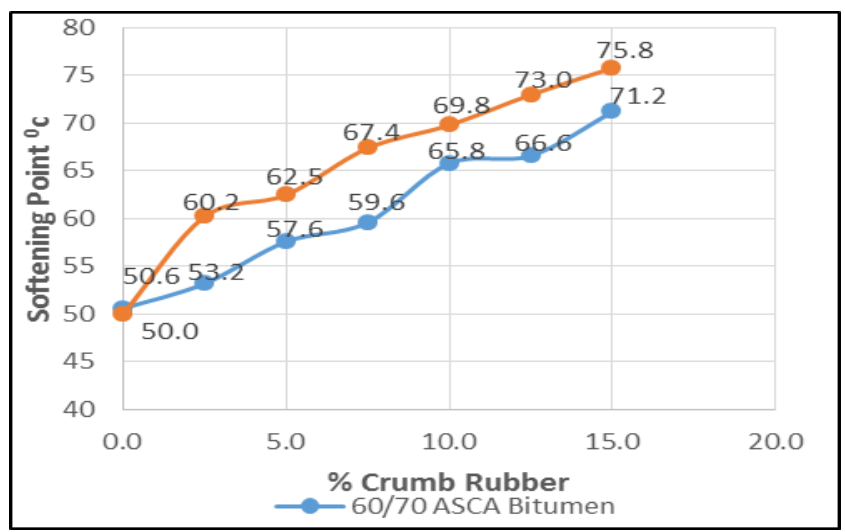

Figure 6: Variation of Softening Point values with Crumb rubber (CR) content

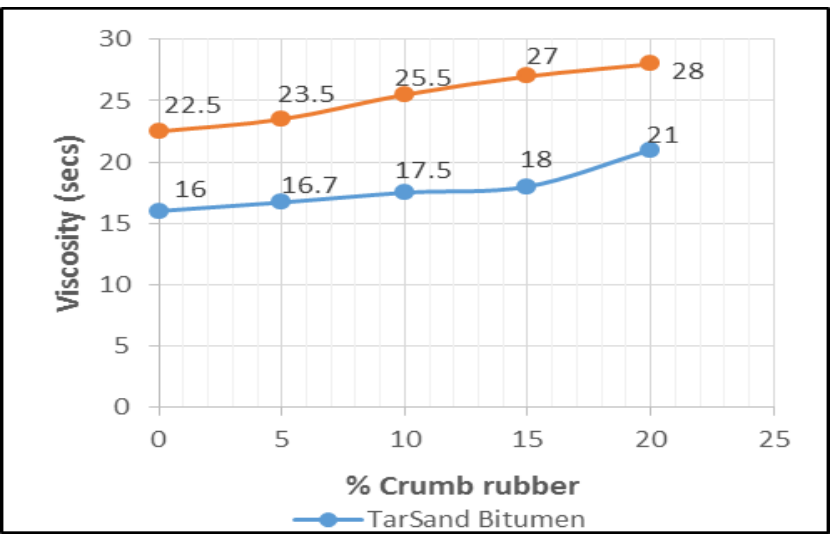

Figure 7: Graph of Viscosity against \% Crumb Rubber

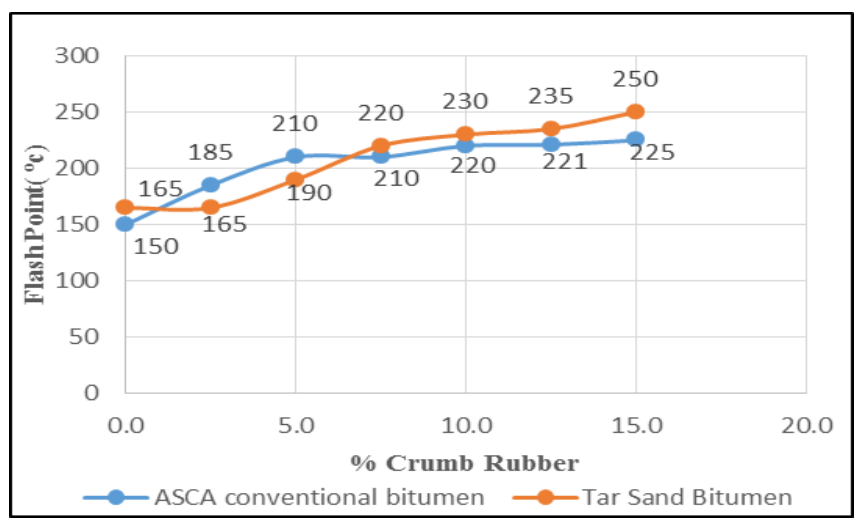

Figure 8: Graph of Flash Point against \% Crumb Rubber

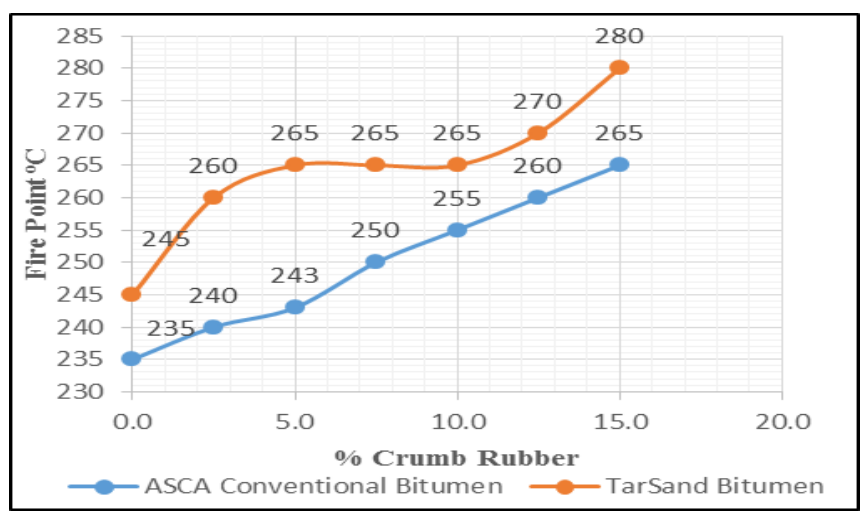

Figure 9: Graph of Fire Point against \% Crumb Rubber

\section{CONCLUSIONS}

From the results of the investigation carried out within the scope of the study, the following conclusions can be drawn:

- Tar Sand collected contained an average of $7.3 \%$ bitumen content. The gradation shows more than $90 \%$ of the sand retained on the $75 \mathrm{~mm}$ sieve. Tar sand bitumen had an average penetration value 82 pen (Grade 80/100) and Softening Point of $50^{\circ} \mathrm{C}$.

- The use of crumb rubber decreases the penetration value of both Bitumen types (Tarsand bitumen and $60 / 70$ conventional bitumen) and increased the Softening point, Viscosity, Flash and Fire point, and Specific gravity values of Tarsand bitumen and conventional 60/70 bitumen.

- Asphalt modification by crumb rubber provides benefit through improvement of rutting resistance and reduction of fatigue/reflection cracking due to higher viscosity and softening point; thus, improving the service life of pavement and lowering pavement maintenance costs.

\section{REFERENCES}

[1] M. O. Ojeyemi, O. E Akintomiwa., G. O. Adediran, H. O. Bakare . The Performance of Agbabu Natural Bitumen Modified with Polyphosphoric Acid through Fundamental and Fourier Transform Infrared Spectroscopic Investigations. www.elsevier.com/locate/cscm. Case Studies in Construction Materials 5 (39-45), 2016

[2] Ministry of Mines and Steel Development. On the Road to Shared Mining Prosperity. www.minesandsteel.gov.ng [quoted March 2018].

[3] A. A. Mohamed, Study on The Physical and Mechanical Properties of Asphaltic Concrete Incorporating Crumb Rubber Produced Through Dry Process. [Online]. Available: http://www.core.ac.uk [Accessed August 2016].

[4] N Tamizharasan, and S Raghuraman, Application of Ground Scarp Tyre in Asphalt Pavement. International Journal of Engineering Science Invention Research \& Development; Vol. I Issue XII June 2015 www.ijesird.com e-ISSN: 2349-6185

[5] A. Akinmosin, and A. O. Shoyemi. Technical Feasibility of Direct Application of the Nigerian Tar Sand Deposits as Road Asphalt. The Pacific Journal of Science and Technology 11(1): 526-536. 2010 